\title{
CORRELATION BETWEEN FACTORS OF PSYCHOLOGICAL PREPARATION AND PHYSICAL CONDITION AND TEAM PERFORMANCE IN LATVIAN YOUTH BASKETBALL
}

\author{
Zermena Vazne \\ Latvian Academy of Sport Education, Riga, Latvia
}

\begin{abstract}
Zermena Vazne. Master in Psychology, Master in Education, Assoc. Prof. at the Department of Pedagogy, Psychology and Sport Theory, Latvian Academy of Sport Education. Researcher at the Teacher Institute in the Latvian Academy of Sport Education. Research interests - the investigation of pedagogical and psychological factors in school age children's sport education and top-level sport.
\end{abstract}

\begin{abstract}
Topicality of the research stems out of theoretically argued and empirically proved facts, analyzing the test results of Latvian youth national basketball teams in the preparation period before the European Championship Games in 2007 and 2008. Scientific investigation of dominating factors of athletes' psychological preparation and physical condition requires research as there is a range of discrepancies: imbalance between the increasing number of important competitions and athletes' inability to maintain concentration for a long time at the necessary level as it affects the quality of performance; the discrepancy between players' opinion about the cohesion level necessary in winning teams and the real situation; imbalance between the belief that psychological preparedness is one of the most important parts of the preparation process and the inability to use theory in practice. Research aim is to evaluate the correlation between the Latvian National Youth Basketball Team players' psychological preparation and physical condition factor structure and performance. The research methods: testing, inquiry, the analysis of game score sheets; mathematical statistics.

Researching team cohesion and team success (performance) in sport, A. Carron, S. Bray and M. Eys (2002) analysed whether team cohesion correlated with team success. They concluded that there was a mutual connection between team cohesion in GI-U and ATG-U scales and team success $(r=0.60$ and $r=0.62(p=0.01))$ and much attention was paid to the content of the ATG-T scale (Carron, Bray, Eys, 2002). But in the research carried out in Latvia the connection between GI-U and GI-S, and team success (performance) $(r=0.60$ and $r=0.598(p=0.01))$ was found. "Success" was characterized by ranged percentage of team wins and loses (their rank was processed with the help of SPSS programme). We suppose that the differences were determined by applying different research design or the differences in the players' mentality.

In the course of the research the criteria to evaluate the content of the factor structure elements were established and the recommendations to improve the content were developed. As a result of the factor analysis of the young basketball players 'psychological preparation and physical condition indices three factors were obtained - "team cohesion", "physical condition and emotional stability", and "motivation and self-regulation". The results in the complex research in Latvian youth teams allow to make suggestions how to optimize basketball players' training, based upon statistically significant correlation coefficients. The analysis of the results shows that working with young Latvian athletes more attention should be paid to the improvement of the players'self-regulation skills, understanding the importance of emotions and emotional conditions in sport, as well as the development of concentration and imagination abilities and to the content of team cohesion structure characterising scale (ATG-T, GI-T, GI-S).
\end{abstract}

Keywords: team cohesion, mental stability, basketball.

\section{INTRODUCTION}

$\mathrm{A}$ long with players' physical, technical and tactical preparation, psychological preparation is of major importance in the training and competition process in sport, including basketball (Moran, 2004; Murphy, 2005; Malinauskas, 2008), and it is based on players' physical condition (Родионов, 2004). The realization of the content of the structure components of psychological preparation and its basis - physical condition - is important not only in professional sport, but also in youth national teams. This question becomes especially topical when the state national teams are preparing for top level competitions, for example, the European Championships (Vazne et al., 2008). 140 coaches in Latvia were asked to answer the question: "What, in your opinion, are three most important conditions that help to achieve higher professional objectives in the 
coach's work and give satisfaction in professional and communicative spheres?" In the research it was stated that according to the Latvian coaches they were as follows: knowledge in psychology, wish to develop and realize oneself creatively, as well as professional preparedness (Vazne, Jansone, 2006). The Irish sport researchers D. Scully and A. Hume investigating top athlete status, knowledge and skills analysed athlete and coaches' opinions on psychological preparedness in sport. The analyses of the results showed that athletes and coaches understood sport psychology mostly as mental preparation in sport. Mental stability is considered to be one of the "most important and necessary" conditions to facilitate achievement in sport (Scully, Hume, 1995). As the second most important factor in team sports "team spirit", "unity” (Weinberg, Gould, 1999), ,team spirit” (Krauliņš, 2008), „team cohesion” (Carron, Brawley, 2000) were mentioned.

The term "mental stability" is often discussed in literature when analyzing athlete performance. Going in for sport facilitates the development of definite qualities in an individual, especially willpower and the ability to overcome "oneself". For an athlete to have secure, predictable and stable performance in tense competition conditions it is necessary to develop a system of skills and abilities that will increase the competition spirit and performance effectiveness. The term "mental stability" was used in sports practice in 1963 (Котло, 2005). Athletes themselves characterize it differently: as the ability and skill to maintain concentration for a long time when playing "under pressure", or as complete control over one's emotions and situation. In 2002 the Irish sport researcher G. Jones defined "mental stability" as the ability to cope with stress or tension, to resist hardships and failures, the ability to continue struggling up to the end in unfavourable conditions (Moran, 2004). According to the research carried out by the Professor J. Portnov in Moscow the factor of success in competitions to a great extent depends on such parts of psychological preparedness structure as team cohesion, performance stability (attention focusing ability, self-regulation and self-control skills, belief in oneself and inner readiness to win), and individual level of alertness. If these elements are absent even super high athlete's functional and technical preparedness can turn out to be insufficient (Портнов, 1997). Physical condition is a very important part of basketball players' preparation. Physical condition is a basis that helps to realize technical and tactical elements in the tense competition conditions. In basketball, an explicitly dynamic sport, accuracy and stability are connected with players' skill to be aware of their emotional condition. Topicality of the research stems out of theoretically argued and empirically proved facts, analyzing the test results of Latvian Youth National Basketball Teams in the preparation period before the European Championship Games in 2007 and 2008. Scientific investigation of dominating factors of athletes' psychological preparation and physical condition requires research as there is a range of discrepancies: the imbalance between the increasing number of important competitions and athletes' inability to maintain concentration for a long time at the necessary level, which affects the quality of their performance; the discrepancy between players' opinion about the cohesion level necessary in winning teams and the real situation; the imbalance between the belief that psychological preparedness is one of the most important parts of the preparation process and the inability to use theory in practice. Research aim was to evaluate the correlation between Latvian National Youth Basketball Team players' psychological preparation and physical condition factor structure and their performance in competitions. Research tasks: to establish the young basketball players' indices of psychological condition (mental stability, team cohesion) and physical condition; to establish and analyse the most significant correlative connections with competition performance; to determine the prevailing factors of psychological preparation and physical condition in youth basketball.

\section{METHODS}

Twelve different Latvian National Youth Basketball teams, both of girls and boys (U-16, U-18, U-20) participated in the research during their preparation period before the European Championship games in 2007 and $2008(n=144)$. The research consisted of three stages. In the first stage the participants were tested. In the second stage the data were processed and recommendations were made for players and coaches. The results of each team were analysed separately, as well as the common results for young females and males. An individual profile of each player was developed, and significant correlations were analysed. The factors of psy- 
chological and physical condition were established using the method of factor analysis. In the third stage the obtained results were showed to the team coaches and they also received recommendations. According to the coaches' wish there were individual discussions with the team players.

The research methods: Testing (GEQ test to establish team cohesion), general physical condition tests; inquiry (STAY - to establish alertness), V. Milman's questionnaire (to determine mental stability); the analysis of game score sheets; mathematical statistics (result procession with SPSS 15 programme).

To state the mental stability, a multi-dimensional V. Milman's questionnaire (Мильман, 1999) was applied. This questionnaire has been successfully used in Lithuania with Lithuanian athletes (Malinauskas, 2001). Analysing the data of the questionnaire made it possible to draw conclusions about athletes' emotional stability during the competitions, the level of self-regulation skills, motivation and the ability to maintain concentration for a long time.

To state the sports team cohesion in sport, the group environment questionnaire (GEQ) version that was adapted in Latvia in the Latvian language and included 18 questions, was used (Vazne, 2008). To state alertness as an individual feature of alertness (T-feature), STAY self-evaluation inquiry version adapted in Latvia in the Latvian language (Škuškovnika, 2004) was applied. The efficiency of the players was calculated using a modified formula (Vazne, Rudzītis, 2007).

\section{RESEARCH RESULTS}

To state young basketball players' components of psychological preparation (psychological stability, team cohesion) the players were tested during their preparation period before the European Championship. Together with psychological components their general physical condition was also tested. The average indices of each team, as well as young players' individual indices were analyzed, and the analysis of the statistically significant correlative values was made. As a result, a distinct dispersion of individual indices in all sub-structures was stated for all the respondents. To evaluate the present situation in Latvia youth basketball the components of young basketball players' prevalent psychological and physical condition factors were stated. First, the correspondence of the respondent groups 2007 and 2008 to make factor analysis by sex and age was evaluated (for the sample of 16 and 18-20 year-old respondents). To evaluate the sample adequacy the Independent Samples Test to compare independent samples and ANOVA test were used.

According to Fisher criterion $(\mathrm{F}=10.467)$ the average indices of the inter-group scale differ significantly as $\mathrm{Sig}=0.01<0.05$ confirming that the diference between the groups accoding to team cohesoin group integration task (GI-T) scale indices is statistically significant (Table 1).

Analysing the differences of inter-groups and inner-groups according to the ATG-S scale, Sig. $=0.04$, we can see that the difference between the groups according to the ATG-S scale indices is statistically significant (Table 2 ).

\begin{tabular}{|l|c|c|c|c|c|}
\hline \multicolumn{7}{|c|}{ ANOVA } \\
\hline GIU & Sum of Squares & df & Mean Square & F & Sig. \\
\hline Between Groups & 372.089 & 1 & 372.089 & 10.467 & 0.001 \\
\hline Within Groups & 5439.008 & 153 & 35.549 & & \\
\hline Total & 5811.097 & 154 & & & \\
\hline
\end{tabular}

Table 1. The differences in team cohesion group integration task (GI-T) scale (ANOVA test) of the 16 and $18-20$ year-old respondent groups of 2007 and 2008

\begin{tabular}{|l|c|c|c|c|c|}
\hline \multicolumn{1}{|c|}{ ATG-S } & Sum of Squares & df & Mean Square & F & Sig. \\
\hline Between Groups & 214.040 & 1 & 214.040 & 8.388 & 0.004 \\
\hline Within Groups & 3904.244 & 153 & 25.518 & & \\
\hline Total & 4118.284 & 154 & & & \\
\hline
\end{tabular}

Table 2. The differences in team cohesion individual attraction to the group social (ATG-S) scale (ANOVA test) of the 16 and $18-20$ years old respondent groups of 2007 and 2008

\begin{tabular}{|l|l|l|l|l|l|}
\hline \multicolumn{1}{|c|}{ Ph_gen } & \multicolumn{1}{c|}{ Sum of Squares } & \multicolumn{1}{c|}{ df } & \multicolumn{1}{c|}{ Mean Square } & \multicolumn{1}{c|}{ F } & \multicolumn{1}{c|}{ Sig. } \\
\hline Between Groups & 29.690 & 1 & 29.690 & 26.361 & 0.000 \\
\hline Within Groups & 168.941 & 150 & 1.126 & & \\
\hline Total & 198.632 & 151 & & & \\
\hline
\end{tabular}

Table 3. The differences according to physical condition (Ph_gen) (ANOVA test) of the 16 and $18-20$ years old respondent groups of 2007 and 2008 
Table 4. Psychological and physical condition factor structure of Latvian youth basketball players

Note. Extraction Method: Principal Component Analysis. Rotation Method: Varimax with Kaiser Normalization. a Rotation converged in 4 iterations.

Team cohesion scales: GI-S, GI-T, ATG-S, ATG-T. Personal alertness (PA). Physical condition ( $\mathrm{Ph}$ gen). Psychical stability scales: emotional stability (ES), motivation component (MC), self-regulation (SR) skills.

Rotated Component Matrix(a)

\begin{tabular}{|l|c|c|c|}
\hline \multirow{2}{*}{ Team cohesion scales } & \multicolumn{3}{|c|}{ Component } \\
\cline { 2 - 4 } & $\mathbf{1}$ & $\mathbf{2}$ & $\mathbf{3}$ \\
\hline GI-S & $\mathbf{0 . 8 5 3}$ & 0.102 & -0.027 \\
\hline GI-T & $\mathbf{0 . 8 3 9}$ & -0.013 & 0.091 \\
\hline ATG-S & $\mathbf{0 . 7 2 6}$ & 0.036 & 0.025 \\
\hline ATG-T & $\mathbf{0 . 5 7 7}$ & 0.095 & 0.215 \\
\hline PA & -0.015 & -0.789 & -0.168 \\
\hline Ph_gen & -0.015 & $\mathbf{0 . 7 0 1}$ & -0.119 \\
\hline ES & 0.227 & $\mathbf{0 . 6 5 2}$ & 0.235 \\
\hline MC & 0.111 & -0.068 & $\mathbf{0 . 8 2 3}$ \\
\hline SR & 0.073 & 0.325 & $\mathbf{0 . 7 8 7}$ \\
\hline
\end{tabular}

Performing the single-factor dispersion analysis to compare independent samples (ANOVA) the obtained double-sided alternative $\mathrm{p}$-values were the biggest in physical condition ( $\mathrm{Ph}$ _gen $)(\mathrm{p}=0.000)$, in this case with the probability of $99 \%$ the means of both samples differ substantially (Table 3 ). There are also strongly distinctive differences in two cohesion structures ATG-S ( $p$-value $=0.004)$ and GI-T structure $(\mathrm{p}$-value $=0.001)$. The results confirm that there are statistically significant differences between the groups. In the further research only the data of 18-20 years old respondents will be analysed. We found statistically significant differences according to age (16 year-old and $18-20$ year-old respondents) in the indices of GI-T; ATG-S, Ph_gen. Therefore for further analysis the sample combining the indices of 18-20 year-old respondents in 2007 and 2008 were used.

The group's correspondence to the factor analysis was tested stating Kaiser-Maijer-Olkin and Bartlet criteria. The value of the KMO (KaiserMeyer-Olkin) criterion for the research sample shows satisfactory correspondence to make factor analysis as the Kaiser-Meyer-Olkin criterion is bigger than the value $0.6(0.629>0.6)$. The significance level of the obtained results is less than 0.05 , thus the research sample data are adequate to make factor analysis ( Sig. $=0.000<0.05$ ). To state the prevailing factors of young basketball players' psychological and physical condition the following methods were used - Extraction Method: Principal Component Analysis and Rotation Method: Varimax with Kaiser Normalization.

As a result of the factor analysis of the young basketball players' psychological and physical condition indices three factors have been obtained - "team cohesion", "physical condition and emotional stability", and "motivation and selfregulation". The structure of the first factor "team cohesion" - is made of four components with the factor weight above 0.5 (GI-T $=0.839$; GI$\mathrm{S}=0.853$; ATG-T $=0.577$; ATG-S $=0.726)$. The structure of the second factor "physical condition and emotional stability" is made of two components: physical condition $(\mathrm{Ph}$ _gen $=0.701)$ and emotional stability $(E S=0.652)$. The structure of the third factor "motivation and self-regulation" is made of two components: self-regulation skills $(\mathrm{SR}=0.787)$ and motivation component $(\mathrm{MC}=0.823)$. In the course of the research the criteria to evaluate the content of the factor structure elements were made and the recommendations to improve the content were developed (Table 4).

\section{DISCUSSION}

The research aim was the evaluation of the correlation of young basketball players' psychological and physical condition factor structure and performance. In the research, analysing Latvia Youth National Team results in 2007 and 2008 in the preparation period before the European Championship mutual correlation coefficients were obtained, and they indicated that team performance had reciprocal statistically significant correlations with the content of other scales. Three factor structure of psychological and physical condition was established in the research.

Four team cohesion components (GI-T; GI-S; ATG-T; ATG-S) had a close correlation with the first factor. The GI-T motive group characterized team players' understanding of the team's general aims and objectives. It helps to make conclusions (but only in connection with the results of other scales) about the players' feelings about "the shared responsibility" in situations of success or failure; about of the team cooperation style, its democracy and openness. GI-S scale characterizes the social motive group. The motive analysis of this group (in connection with the results of other scales) helps 
to draw conclusions about the players' individual perception about how the possibilities of spending common leisure time influence the achievement of aims set for the team. Both scales together help to analyse which factors are present and which are not for the team's participants to feel themselves as "one unit". The ATG motive group shows the players' individual and the team's total aim balance level. ATG-T motive group characterizes the evaluation of the players' individual self-contribution; to what extent there are or there are not mutually balanced the players' individual and the team's aims and objectives. ATG-S characterizes the social motive group what characterizes the players' sense of belonging to a definite group. Analysing the connections of all four scale results it is possible to draw the conclusion to what extent an athlete's sense of belonging to a group as a social unit is connected with professional growth and the possibility to spend the leisure time pleasantly. ATG-T motive group characterizes the players' individual evaluation of self-contribution. It helps to conclude to what extent there are or there are not mutually balanced players' individual and team's aims and objectives. The first factor is "team cohesion".

Two components - the total index of physical condition and emotional stability have close and positive correlation with the second factor. Physical condition ( $\mathrm{Ph}$ _gen) is a very important component of basketball player preparation. Physical condition is the basis that helps to realise technical and tactical elements in the tense competition conditions. Emotional stability (ES) in basketball expresses the players' understanding of their emotions what helps to mobilize them psychologically according to the situation. Usually such players do not allow the opponent to provoke themselves to make forbidden actions. Basically they are the players whose performance is predicted as stable. Such players usually do not worry nor panic about what has not happened yet. They are calm and balanced, rather often a little introvert and they do not worry about trifles. It promotes inner belief about one's strength and ability to show good result. The second factor is "physical condition and emotional stability".

Two components - motivation component $(\mathrm{MC}=0.823)$ and self-regulation skills $(\mathrm{SR}=0.787)$ have close and positive correlation. The motivation component in basketball manifests as wish to dominate, to be a leader, to prove oneself. Such players like to risk, to take responsibility, they like to compete. They willingly do great amount of work, they always contribute substantially. They have serious attitudes towards what they do (sometimes the very high sense of responsibility can disturb). In order to achieve the sports aim they are ready to sacrifice a lot. But an inseparable part of successful leadership is a skill to adjust and change flexibly according to the situation. This component correlates negatively with self-regulation skills, that is, the skill to regulate one's emotions deliberately (Vazne, Larins, Rudzitis, 2007). When the self-regulation skills increase, so do the concentration skills of deliberate attention. They influence the players' skills to "focus" their attention on the game process maximally, standing apart from side hindrances, and vice versa. The structure of the third factor is made of two components with factor weight above $0.6(\mathrm{MK}=0.823 ; \mathrm{SR}=0.787)$. The third factor is "motivation and self-regulation".

Performing correlative team cohesion and team success (performance) in sport analysis, A. Carron, S. Bray and M. Eys (2002) analysed whether team cohesion correlates with team success. It was stated in the research that there is a mutual connection with team cohesion in GI-U and IPG-U scales and team success $r=0.60$ and $r=0.62(p=0.01)$, much attention was paid to the content of the ATG-T scale (Carron, Bray, Eys, 2002). But in the research carried out in Latvia the following connection GI-U and GI-S, and team success (performance) $r=0.60$ and $r=0.598(p=0.01)$ was established. "Success" was characterized by ranged percentage of team wins and loses (Rank was processed with the help of SPSS programme). We suppose that the differences were determined by the different research design or the differences in the players' mentality.

The motivation component $r=0.597$ to $\mathrm{r}=0.765(\mathrm{p}=0.05)$ also has a correlation with the GI-T scale. Emotional stability and physical condition correlates with the (Reb tot) total number of the balls won $(r=0.403 ; r=0.446)$, players' effectiveness coefficient in games $(r=0.429)$ and self-regulation skills $(\mathrm{r}=0.471), \mathrm{p}=0.01$. Self-regulation skills show a close correlation with players' effectiveness coefficient in games $(\mathrm{r}=0.813 ; \mathrm{p}=0.05)$.

The highest $3^{\text {rd }}$ place in the 2007 European Basketball Championship in A division was won by Latvia U-18 Junior national team having high indices in all "team cohesion" structures (ATG-T $=30.5 \pm 2.5$; ATG-S $=36.75 \pm 4.57$; GI$\mathrm{T}=43.62 \pm 1.77$; GI-S $=33.87 \pm 2.17$ ); their indices of "motivation and self-regulation" structure 


\begin{tabular}{|c|c|c|c|c|c|c|c|c|c|c|}
\hline \multirow{6}{*}{$\begin{array}{l}\text { Table 5. Descriptive } \\
\text { statistical results of } \\
\text { Latvian basketball players } \\
\text { (European Championship- } \\
\text { 2007) }\end{array}$} & 2007 & Values & ATG-T & ATG-S & GI-T & GI-S & ES & SR & MC & St \\
\hline & U_16_f & Mean & & & & & -2.8 & -0.8 & 2.3 & -2.9 \\
\hline & & Std. dev & & & & & 2.25 & 2.3 & 1.5 & 1.3 \\
\hline & U_18_f & Mean & 29.71 & 32.85 & 27.9 & 19.1 & -2 & -2 & 1.9 & -1.7 \\
\hline & & Std. dev & 2.63 & 4.18 & 5.14 & 2.48 & 2.16 & 2.6 & 1.2 & 1.9 \\
\hline & U_20_f & Mean & 25.5 & 34.25 & 25.9 & 19.8 & -2.4 & -1 & 2.1 & -0.5 \\
\hline \multirow{7}{*}{$\begin{array}{l}\text { Note. Team cohesion sca- } \\
\text { les: GI-S, GI-T, ATG-S, } \\
\text { ATG-T. Psychical stability } \\
\text { scales: emotional stability } \\
\text { (ES), self-regulation (SR) } \\
\text { skills, (MC) motivation } \\
\text { component, (St) performan- } \\
\text { ce stability. }\end{array}$} & & Std. dev & 3.2 & 5.99 & 4.39 & 5.67 & 2.06 & 2.8 & 1.6 & 1.8 \\
\hline & U-16_m & Mean & 29.44 & 36.22 & 31.3 & 25.7 & -2.8 & -0.1 & 1.8 & -1.2 \\
\hline & & Std. dev & 5.31 & 6.53 & 5.87 & 7.41 & 2.1 & 2.6 & 2.6 & 1.5 \\
\hline & U_18_m & Mean & 30.5 & 36.75 & 43.62 & 33.87 & 0 & 0.4 & 1.8 & -1.8 \\
\hline & & Std. dev & 2.5 & 4.56 & 1.77 & 2.17 & 1.77 & 2.9 & 2.6 & 1.5 \\
\hline & U_20_m & Mean & 24.71 & 33.86 & 32.7 & 29 & -1.7 & -1.3 & 2.1 & -1.1 \\
\hline & & Std. dev & 7.45 & 7.13 & 6.9 & 5.13 & 1.89 & 3.2 & 2.9 & 2.5 \\
\hline \multirow{13}{*}{$\begin{array}{l}\text { Table 6. Descriptive } \\
\text { statistical results of } \\
\text { Latvian basketball players } \\
\text { (European Championship- } \\
\text { 2008) }\end{array}$} & 2008 & & ATG-T & ATG-S & GI-T & GI-S & ES & SR & MC & St \\
\hline & U_16_f & Mean & 27.78 & 42.67 & 26.7 & 25.1 & -2.1 & -2.7 & 1.2 & -3.3 \\
\hline & & Std. dev & 1.79 & 2 & 3 & 4.01 & 1.36 & 1.4 & 3.5 & 1.5 \\
\hline & U_18_f & Mean & 29.27 & 38.91 & 38.9 & 31 & -1.9 & -0.8 & 2.6 & -1.9 \\
\hline & & Std. dev & 3.16 & 3.42 & 2.7 & 2 & 1.81 & 1.5 & 1.7 & 1.8 \\
\hline & U_20_f & Mean & 28 & 35.25 & 33.1 & 27.3 & -1.9 & -1 & 2.3 & -2.5 \\
\hline & & Std. dev & 6.04 & 1.67 & 5.96 & 2.25 & 2.47 & 2.3 & 0.9 & 2.5 \\
\hline & U-16_m & Mean & 29.5 & 36.8 & 33.4 & 29.8 & -1.9 & -0.6 & 1.9 & -1.6 \\
\hline & & Std. dev & 4.97 & 7.13 & 5.21 & 4.31 & 2.13 & 1.6 & 2.3 & 1.6 \\
\hline & U_18_m & Mean & 29.6 & 35.6 & 33.4 & 28.4 & -2 & -0.2 & 1.8 & -1.7 \\
\hline & & Std. dev & 2.5 & 4.17 & 3.69 & 1.84 & 1.49 & 2.3 & 2.3 & 1.3 \\
\hline & U_20_m & Mean & 29.5 & 38.1 & 30.8 & 26.7 & -2 & -0.8 & 2.9 & -2 \\
\hline & & Std. dev & 4.2 & 4.6 & 4.13 & 3.16 & 1.87 & 1.2 & 1.3 & 1.9 \\
\hline
\end{tabular}

were above the average level: self-regulation skills $(\mathrm{SR}=0.37 \pm 2.92)$, the indices of the motivation component $(\mathrm{MC}=1.75 \pm 2.6)$. Low dispersion indices are characteristic of balanced teams (Table 5). Analysing mutual correlations in this team (U-18, male) close connection in GI-S and GI-T scales $(\mathrm{r}=0.956 ; \mathrm{p}=0.01)$ has been stated.

The $1^{\text {st }}$ place in 2008 European Basketball Championship in B division was won by Latvian U-18 young females (U_18_f). Their average indices in all structures were higher than the ones of the other five teams (Table 6).

In the research carried out in Latvia it was found that athletes whose performance in the decisive competitions is usually high are characterized by achievement motives, good understanding of their emotional conditions, developed self-regulation skills, the ability to maintain concentration for a long time, the ability to play "under pressure", confidence about the correctness of the coach's and their own actions. Analysing the research, it is possible to conclude that the components that form "the team collective strength" are higher for the teams which have won top places in the Euro- pean Championship and the final tournaments of Latvian basketball league (Vazne et al., 2008).

\section{CONCLUSIONS}

- As a result of the factor analysis of the young basketball players' psychological preparation and physical condition indices three factors have been obtained - "team cohesion", "physical condition and emotional stability", and "motivation and self-regulation".

- The results in complex research in Latvian youth teams allow making suggestions how to optimize basketball players' training, based upon statistically significant correlation coefficients.

- The analysis of the results shows that working with young Latvian athletes much attention should be paid to the improvement of the players' self-regulation skills, understanding of the importance of emotions and emotional conditions in sport, as well as to the development of concentration and imagination abilities and to the team cohesion structure characterising scale (ATG-T, GI-T, GI-S) content. 


\title{
REFERENCES
}

Carron, A., Bray, S., Eys, M. (2002). Team cohesion and team success in sport. Journal of Sport Sciences, 20 (2), $118-119$

Carron, A. V., Brawley, L. R. (2000). Cohesion: Conceptual and measurement issues. Small Group Research, 31, 89-106.

Kraulinšs, A. (2008). Internet link: http://easyget.lv/sports/ $\mathrm{read} / 8407$ no 11.08 .2008 18:25

Malinauskas, R. (2001). Didelio meistriškumo dviratininku psichinio patikimumo ypatumai. Sporto mokslas, $2(20), 42-45$.

Malinauskas, R. (2008). The influence of phychological training program on the psychological skills in elite basketball players. Sporto mokslas, 2 (52), 6-11.

Moran, A. P. (2004). Sport and Exercise Psychology: A Critical Introduction. Library of Congress Cataloging in Publication Data. Tailor\&Francis Group.

Murphy, S. (2005). The Sport Psychology Handbook (Chapter 8, pp. 127-151). US: Human Kinetics Publishers, Inc.

Scully, D., Hume, A. (1995). Sport psychology: Status, knowledge and use among elite level coaches and performers in Ireland. The Irish Journal of Psychology, 16, $52-66$.

Škuškovnika, D. (2004). Trauksme latviešiem un Latvijā dzīvojošiem krieviem. Promocijas darba kopsavilkums. Rìga: LU Pedagog̣ijas un psihologijas fakultāte.

Vazne, Ž., Jansone, R. (2006). Trenera radošums un pašaktualizācijas vērtēšana. Radoša personība IV (pp. 130-
138). Zinātnisko rakstu krājums. Rīga: RaKa.

Vazne, Z., Larins, V., Rudzitis, A. (2007). Psychophysiological qualification for young basketball players. $5^{\text {th }}$ International Baltic Congress of Sports Medicine. Abstract Book (pp. 25-26). Vilnius.

Vazne, Z. (2008). Psychometric properties of the Latvian version of the group environment questionnaire test. Sporto mokslas, 2 (52), 12-16.

Vazne, Z., Rudzītis, A. (2007). Komandas saliedētības struktūras dinamika 15-18 gadus veciem basketbolistiem. LSPA zinātniskie raksti (pp. 191-203). Rīga: LSPA.

Vazne, Ž., Rudzītis, A., Lāriṇš, V. (2008). Jauno basketbolistu psihologiskās sagatavotības faktoru struktūra. ATEE Spring University. Teacher of the 21st Century: Quality Education for Quality Teaching (pp. 126-134). Rīga: LU.

Weinberg, R., Gould, D. (1999). Foundations of Sport and Exercise Psychology. Champaign, Illinois: Human Kinetics.

Котло, Е. (2005). Механизмы эмоииональной детерминированности внутреннего отсчёта времени спортсменов: дисертация. Ставрополь.

Мильман, В. (1999). Психодиагностика в спорте. Москва: Просвещение.

Портнова, Ю. (Ред.) (1997). Баскетбол. Москва: VIR Print.

Родионов, А. (2004). Психология физического воспитания и спорта. Москва: Фонд «Мир».

\section{PSICHOLOGINIO, FIZINIO RENGIMO IR DALYVAVIMO VARŽYBOSE RODIKLIŲ KORELIACIJA SU LATVIJOS JAUNŲJŲ KREPŠININKŲ PASIRODYMU}

\author{
Zermena Vazne \\ Latvijos kūno kultūros akademija, Ryga, Latvija
}

\section{SANTRAUKA}

Treniruočiu, varžybu metu be fizinio, techninio ir taktinio rengimo, psichologinis sportininku rengimas taip pat labai svarbus (Moran, 2004; Murphy, 2005; Malinauskas, 2008) ir glaudžiai siejasi su fizine žaidejo būsena (Родионова, 2004). Tyrimo reikšmingumą nusako teoriškai argumentuoti ir empiriškai pagrịsti faktai analizuojant Latvijos jaunių krepšinio rinktinès pasirengimo Europos čempionato žaidynèms 2007 ir 2008 metais rezultatus. Tyrimo tikslas — ivertinti Latvijos jaunių krepšinio rinktinės narių psichologinio rengimo bei fiziniu savybių ir pasirodymo rezultatų koreliaciją. Tyrimo uždaviniai: nustatyti jaunuju krepšininkų psichologinès (psichinio stabilumo, komandos sutelktumo) ir fizinès būsenos rodiklius; nustatyti ir išanalizuoti reikšmingiausius koreliacinius ryšius su pasirodymo varžybose rezultatais; nustatyti vyraujančius jaunuju krepšininku psichologinio rengimo ir fizinès būklès veiksnius. Tyrimo metodai: testavimas (GEQ testas komandos sutelktumui ịvertinti), bendrosios fizinès būklès testas, apklausa (STAY — judrumui ịvertinti), V. Milman anketa psichologiniam stabilumui įvertinti, žaidimo protokolų analizè, matematinè statistika (rezultatai apdoroti SPSS programa).

Latvijos jauniu krepšinio rinktinès nariu psichologinès ir fizinės būsenos komponentu indeksu analizè leido išskirti tris veiksnius: pirmą - komandos sutelktumą, antrą - fizinę būseną ir emocinị stabilumą, 
trečią - motyvaciją ir savireguliaciją. Tiriant buvo išskirti šių veiksnių struktūrinių elementų turinio Łvertinimo kriterijai ir pateiktos rekomendacijos šiam turiniui tobulinti. Pirmo veiksnio (komandos sutelktumo), sudaryto iš keturiu komponentu, reikšmé didesnè nei 0,5 (GI-T =0,839; GI-S $=0,853$; ATG$\mathrm{T}=0,577$; ATG-S $=0,726$ ). Antrą veiksnị (fizinę būseną ir emocini stabiluma) sudaro du komponentai bendra fizinè būsena $\left(\mathrm{Ph} \_\right.$gen $\left.=0,701\right)$ ir emocinis stabilumas $(\mathrm{ES}=0,652)$. Trečią veiksnị (motyvaciją ir savireguliaciją) taip pat sudaro du komponentai - savireguliacijos igūdžiai $(\mathrm{SR}=0,787)$ ir motyvacijos komponentas $(\mathrm{MK}=0,823)$. Nustatytas ryšys tarp GI-T ir GI-S skalių ir dalyvavimo varžybose (rodiklių rango vieta $r=0,60$ ir $r=0,598(p<0,001)$. ATG-S rodikliai labai silpnai koreliuoja su laisvuju metimu skaičiumi (FT\%) $(r=0,355, \mathrm{p}<0,005)$, ir nustatytas skirtumas tarp lyčių. Emocinis stabilumas ir fizinè būsena koreliuoja su atkovotų kamuolių skaičiumi (Reb_tot) $r=0,403(p<0,005) ; r=0,446(p<0,001)$. Emocinio stabilumo rodikliai koreliuoja su žaidejų veiksmingumo rungtynèse koeficientu $(r=0,429)$ ir savireguliacijos igūdžiais $(\mathrm{r}=0,471(\mathrm{p}<0,005))$. GI-T skalès rodikliai koreliuoja su motyvacijos komponentų skale $(\mathrm{r}=0,597$ iki $\mathrm{r}=0,765(\mathrm{p}<0,005))$. Savireguliacijos rodikliai stipriai koreliuoja su žaidejjų veiksmingumo rungtynèse koeficientu $(\mathrm{r}=0,813(\mathrm{p}<0,005))$.

Gautų duomenų analizè rodo, kad dirbant su jaunaisiais sportininkais reikia daugiau dèmesio skirti žaidèjų savireguliacijos igūdžių ugdymui, savo emocijų supratimui ir teigiamų emocijų skatinimui, dèmesio lavinimui, vaizduotès ugdymui, taip pat komandos sutelktumo kūrimui pagal skalių ATG-T, GI-T, GI-S turini. Aukščiausią (trečią) vietą 2007 metų Europos krepšinio čempionate A lygoje yra iškovojusios Latvijos U-18 jaunių rinktinès sutelktumo indeksai labai aukšti (ATG-T $=30,5 \pm 2,5$; ATG-S $=36,75 \pm 4,56$; GI-T $=43,62 \pm 1,77$; GI-S $=33,87 \pm 2,17$ ). Motyvacijos ir savireguliacijos indeksai taip pat aukštesni už vidutinius: savireguliacijos igūdžiai $-\mathrm{SR}=0,37 \pm 2,92$; motyvacijos $-\mathrm{MK}=1,75 \pm 2,6$. Pirmają vietą 2008 metų Europos krepšinio čempionate B lygoje laimèjusios U-18 merginų komandos narių visi rodikliai buvo aukštesni nei kitu penkių komandų.

Raktažodžiai: komandos sutelktumas, psichinis stabilumas, krepšinis.

Gauta 2008 m. spalio 2 d.

Received on October 2, 2008

\section{Zermena Vazne}

Latvian Academy of Sport Education

(Latvijos kūno kultūros akademija)

Brivibas str. 333, LV 1006 Riga

Latvia (Latvija)

Tel +37167543430

E-mail z.vazne@e-teliamtc.lv 